\title{
Emotional Intelligence Through Mathematical Resilience Secondary Students Based on Gender
}

\author{
Ayu Faradillah ${ }^{1 *}$, Silvi Wulandari ${ }^{2}$ (iD \\ 1,2,3 Universitas Muhammadiyah Prof. DR. HAMKA, Jakarta Timur, Indonesia \\ *Corresponding author: ayufaradillah@uhamka.ac.id
}

\begin{abstract}
The low mathematical resilience of students, one of the factors is the fear of being wrong so that it shows things related to students' emotions. Mathematical resilience and emotional intelligence are interrelated, therefore students need to develop mathematical resilience and emotional intelligence to be ready to face challenges and be able to learn optimally. The purpose of this study is to analyze mathematical resilience on students' emotional intelligence based on gender in twelve different schools. The method used is descriptive qualitative. The population of this study was 814 students consisting of 301 male students and 513 female students. The selection of subjects in this study by looking at the category of Mathematical Resilience, namely high, medium and low. Subjects were selected using the Winsteps application by looking at the wright map table. From the total population, the researcher chose three subjects to be studied in depth. Furthermore, the selected subjects were asked to fill out an Emotional Intelligence questionnaire and interviewed by the researcher. The results of the analysis of ST who have high Mathematical Resilience have high Emotional Intelligence, ST are able to control themselves and have high interest in learning mathematics, SS who have moderate Mathematics Resilience have moderate Emotional Intelligence. In the learning process, SS does not focus on learning and is less able to explore its potential in depth. SR who have low Mathematical Resilience have low Emotional Intelligence as well. SR tends to give up easily and has low learning motivation. However, it should be noted that there is no gender difference in Emotional Intelligence, because this is based on the instrument or measuring instrument used in the study.
\end{abstract}

Keywords: Mathematical Resilience; Emotional Intelligence; Winsteps

\begin{tabular}{ll}
\hline History: & Publisher: Undiksha Press \\
Received : April 04, 2021 & Licensed: This work is licensed under \\
Revised : April 22, 2021 & a Creative Commons Attribution 3.0 License \\
Accepted : June 18, 2021 &
\end{tabular}

\section{INTRODUCTION}

Mathematical Resilience (MR) is very necessary for learning mathematics because the nature and impression of mathematics is a very difficult subject for most students and the lack of practice and high competitiveness with peers results in students feeling anxious and avoiding anything related to mathematics so that it disturbs student achievement (JohnstonWilder \& Lee, 2019; Laelasari et al., 2019). The problem of resilience is largely the domain of psychologists, sociologists, and mental health professionals it is known that the influencing factors are internal and external (Permatasari et al., 2021; Rosowsky, 2020). MR is not an instant thing but needs to be trained and developed (Ruqoyyah et al., 2020). to cultivate strong students begins with being ready to face risks, facing challenges as opportunities to learn, and believing that in learning these students can develop better (Moala \& Hunter, 2019). Strong students are formed because of disciplined and independent behaviour resulting in positive student character in learning mathematics so that these students do not give up easily in the face of failure, can solve problems well, look for new strategies and make maximum efforts in solving a problem (Harsela et al., 2021; Pieronkiewicz \& Szczygieł, 2020; Rohmah et al., 2020). Whereas students with low MR often experience anxiety and difficulty in dealing with problems and cannot solve them so that students' mathematics learning achievement is also low (Rohmah et al., 2020; Rokhmah et al., 2019). Thus, students are expected to have a high MR so that they can face all 
problems in learning mathematics (Joy, 2019; Muntazhimah \& Ulfah, 2020). MR is a concept of abilities and soft skills that a person must have in facing difficulties and obstacles well so that they can struggle harder in learning mathematics (Amelia et al., 2020; Hendriana et al., 2019; Hutauruk et al., 2019; Ishak et al., 2020). Students' mathematical resilience can be developed through formal and informal environments (Pieronkiewicz \& Szczygiel, 2020). Based on some of these studies, one of the factors of low MR is the fear of being wrong which indicates that it is related to student's emotions. This is reinforced by previous research which states that resilience is significantly related to students' emotional intelligence (Ngui \& Lay, 2020).

Emotional intelligence has an important role in regulating one's actions in interacting with others (Okwuduba et al., 2021). 35.7\% of emotional intelligence affects learning outcomes (Jannah et al., 2019). Emotional intelligence must cultivate behaviours that are usually essential to facilitating productive persistence in stressful situations (Udayar et al., 2020). Low emotional intelligence experiences stress levels with high acculturation and tend to procrastinate so that it can hinder students' ability to reach academic potential, and cannot manage emotions at a higher level (Fteiha \& Awwad, 2020; Prentice et al., 2020; Tam et al., 2021). Emotional intelligence is not merely an inherited trait but can be improved and developed through coaching (Nayar et al., 2020). To reach academic potential, students need to develop strong emotional or mental skills in facing challenges in order to become better (Jan \& Anwar, 2019; MacCann et al., 2019). Because the more emotionally intelligent a person is, the better his academic achievement is and the better the person is in recognizing and managing his emotions (Chinyere \& Afeez, 2019). Students not only need academic skills but also need to manage social and emotional skills in order to be able to perform well academically (Blaik Hourani et al., 2020; Mahmud, 2020). Teacher and student mental skills are very important to improve emotional intelligence so that it has a significant impact on mathematics achievement (Halimi et al., 2020; Pozo-Rico \& Sandoval, 2020). Hence, student's mind is related to Emotional Intelligence (Joy, 2019; Nugroho et al., 2019). Emotional Intelligence (EI) generally has the same meaning from some experts, namely the ability or skill of a person to recognize and respond to emotions appropriately, motivate, empathize, and control oneself and others (Chinyere \& Afeez, 2019; Mansir \& Karim, 2020; Ngui \& Lay, 2020; Pekaar et al., 2020; Perry et al., 2020; Wood, 2020). In other words, EI is another type of intelligence in a person's thinking that allows him to logically control and adapt to his environment (Kustyarini, 2020; Trigueros et al., 2019). In developing emotional intelligence, a person is influenced by the environment. A conducive environment affects a person's success (Hadi \& Faradillah, 2019) because someone can grow and develop well.

There is a research focus of interest to researchers. First, Ugwuanyi's research on emotional intelligence and self-efficacy on student achievement. Second, Chinyere \& Afeez's research on emotional intelligence on academic motivation and learning attitudes. Third, Prayogi's research on the relationship between domicile status and the student's Grade Point Average (GPA). Fourth, Joy's research on motivation and emotional intelligence on students' mathematical resilience. Based on the results of the above research, Ugwuanyi stated that there was a positive relationship between students' emotional intelligence and mathematics learning achievement (Ugwuanyi et al., 2020). In addition, the results of other studies also show that emotional intelligence affects several things, such as learning motivation, student's Grade Point Average (GPA) and mathematical resilience (Chinyere \& Afeez, 2019; Joy, 2019; Prayogi et al., 2019). There is a gap in these four studies, namely comparing how MR affects emotional intelligence based on the gender. Therefore, the novelty of this study lies in students' mathematical resilience on emotional intelligence based on their gender. The purpose of this study is to analyse, and define students' Emotional Intelligence through Mathematical Resilience. 


\section{MATERIALS AND METHODS}

The method used in this research is descriptive qualitative, namely research whose results are in accordance with the words of the researcher. The instruments used in this study were MR and Emotional Intelligence questionnaires. The MR instrument was used to determine students' high, medium and low mathematical resilience. The MR instrument consisted of responses on a scale of 1 to 7 with the statements of strongly agree, agree, somewhat agree, neutral, somewhat disagree, disagree and strongly disagree. This study was developed from previous research instruments which had been adjusted to language structures and mathematics learning. This instrument was validated by three validators, namely two lecturers and one teacher. The three validators stated that the questionnaire was feasible to use with improvement, namely language improvement so that it was easier for students to understand. The number of populations in this study were 814 students from 12 junior high schools in three different provinces, namely DKI Jakarta, West Java and Banten with a total of 301 male students and 513 female students. The population in this study was given the MR questionnaire first.

Table 1. The Indicators of Mathematical Resilience Questionnaire

\begin{tabular}{cccc}
\hline No & Indicators of Mathematical Resilience & Statement Item Number & Total \\
\hline 1 & Value & $1,2,3,4,5,6$ & 6 \\
2 & Struggle & $7,8,9,10,11,12,13$ & 7 \\
3 & Growth & $14,15,16,17,18,19,20,21$ & 8 \\
4 & Resilience & $22,23,24,25,26,27,28,29$, & 14 \\
\hline
\end{tabular}

(Kooken et al., 2015)

The indicators in this research instrument are divided into four, namely value, struggle, growth, and resilience. MR subjects are taken by using the Rasch WinStep model software, and they are analyzed to determine student's responses based on the questionnaire that is distributed (Faradillah \& Febriani, 2021), and the table used is Wright Maps. Wright Maps is a very complex technique for displaying ranking scale data and test data that explains the covariance of all items (Palumbo et al., 2020). The analysis in this study was seen based on gender. In this study, the focus was on these three categories. The researcher took one subject from each category, namely high, medium and low. MR categories are presented in Table 2.

Table 2. The Research Subjects Based on MR

\begin{tabular}{cccc}
\hline No & Category & Gender & Code \\
\hline 1 & High & Female & ST \\
2 & Medium & Male & SS \\
3 & Low & Female & SR \\
\hline
\end{tabular}

The total population of 814 students consisted of 301 male students and 513 female students. The researcher randomly selected the subjects based on high, medium, and low categories. From the three categories, the researcher chose one subject from each category. Because the focus of this study was on gender, the researcher chose three subjects with different gender. In the high category, the researcher chose females, and she was given an ST code. In the medium category, the researcher chose a male, and he was given an SS code. Finally, for the low category, the researcher chose females, and she was given an SR code. 


\section{RESULTS AND DISCUSSION}

\section{Results}

After selecting a subject from each category, the researcher provided a second research instrument in the form of an Emotional Intelligence questionnaire. The following is the percentage statement of emotional intelligence instruments:

Table 3. The Percentage Statement of Emotional Intelligence

\begin{tabular}{|c|c|c|c|c|}
\hline Statement & $\begin{array}{c}\text { Totally } \\
\text { Disagree }\end{array}$ & Disagree & Agree & $\begin{array}{l}\text { Strongly } \\
\text { agree }\end{array}$ \\
\hline $\begin{array}{l}\text { When I understand math material, I can } \\
\text { easily teach others }\end{array}$ & - & $66,67 \%$ & - & $33,33 \%$ \\
\hline $\begin{array}{l}\text { When I have trouble learning math, I easily } \\
\text { ask other people questions }\end{array}$ & - & $33,33 \%$ & $33,33 \%$ & $33,33 \%$ \\
\hline $\begin{array}{l}\text { It is not easy for me to ask questions when I } \\
\text { have a hard time learning math }\end{array}$ & - & $100 \%$ & - & - \\
\hline $\begin{array}{l}\text { I find it difficult to explain math material to } \\
\text { other people }\end{array}$ & $33,33 \%$ & $66,67 \%$ & - & - \\
\hline $\begin{array}{l}\text { It is easy for me to understand my friends if } \\
\text { they have trouble learning math }\end{array}$ & - & $33,33 \%$ & $66,67 \%$ & - \\
\hline $\begin{array}{l}\text { I try to respect the way other people solve } \\
\text { math problems }\end{array}$ & - & - & $66,67 \%$ & $33,33 \%$ \\
\hline I can understand math easily & - & $33,33 \%$ & $33,33 \%$ & $33,33 \%$ \\
\hline $\begin{array}{l}\text { When my friends don't understand the math } \\
\text { material taught by the teacher, I can } \\
\text { understand }\end{array}$ & - & $100 \%$ & - & - \\
\hline $\begin{array}{l}\text { I can still solve math problems even when } \\
\text { I'm upset }\end{array}$ & $33,33 \%$ & $33,33 \%$ & $33,33 \%$ & - \\
\hline $\begin{array}{l}\text { I find it hard to control my anger when my } \\
\text { math scores are down }\end{array}$ & $33,33 \%$ & $66,67 \%$ & - & - \\
\hline $\begin{array}{l}\text { I find it hard to control my anger when my } \\
\text { math scores are down }\end{array}$ & - & $33,33 \%$ & $66,67 \%$ & - \\
\hline $\begin{array}{l}\text { When my exam time got less I could } \\
\text { answer questions without thinking }\end{array}$ & - & $100 \%$ & - & - \\
\hline $\begin{array}{l}\text { I try to persist in doing math problems until } \\
\text { I get an answer }\end{array}$ & - & $66,67 \%$ & $33,33 \%$ & - \\
\hline $\begin{array}{l}\text { I can provide answers to tough math } \\
\text { questions }\end{array}$ & $33,33 \%$ & $66,67 \%$ & - & - \\
\hline $\begin{array}{l}\text { When answering a difficult math question, I } \\
\text { try to think of multiple solutions to solve it }\end{array}$ & - & $33,33 \%$ & $66,67 \%$ & - \\
\hline $\begin{array}{l}\text { Sometimes I find it difficult if I am given } \\
\text { new math material by the teacher }\end{array}$ & $33,33 \%$ & $66,67 \%$ & - & - \\
\hline $\begin{array}{l}\text { I have positive ideas when studying } \\
\text { mathematics }\end{array}$ & - & $33,33 \%$ & $66,67 \%$ & - \\
\hline When studying math, no one can bother me & $100 \%$ & - & - & - \\
\hline $\begin{array}{l}\text { I like all the material in learning } \\
\text { mathematics }\end{array}$ & $33,33 \%$ & $33,33 \%$ & $33,33 \%$ & - \\
\hline I feel confident doing math exams & $33,33 \%$ & $33,33 \%$ & $33,33 \%$ & - \\
\hline
\end{tabular}


The results showed that ST with high MR category also had high Emotional Intelligence, SS with medium MR category also had moderate Emotional Intelligence, and SR with low MR category had low Emotional Intelligence. This is in line with Joy's research that Emotional Intelligence is estimated to have a significant effect on MR (Joy, 2019). To strengthen the results of the analysis, researchers interviewed the subjects under study. The interview guidelines used were unstructured interviews because researchers did not use the structured interview guidelines that had been previously prepared. However, the researcher used the interview guidelines whose questions were mostly about the problem that would be asked. The excerpts from the interview with each research subject based on indicators of Emotional Intelligence are as follows:

\section{The result of the interview with ST on each indicator of emotional intelligence}

There are four statements in the first indicator which is Intrapersonal Skills. Below is the excerpt from the interview which results in the statement "I do not easily ask when it is difficult to learn mathematics."

Researcher: What will you do if you have trouble learning math?

ST : I will study and reread my notes to understand it deeper

Next, there are four statements in the second indicator which is Interpersonal Skills. The excerpt from the interview with ST below results in the statement "I try to respect the way other people solve math problems."

Researcher: If during an exam, the way you solve the problem is different from your friend and you think the answers are both correct. How do you react to it?

ST : I will react well to it because even though the answer is the same, but with different formulas, all of them will have their own answer.

Moreover, there are four statements in the third indicator which is Stress Scale. Below is the excerpt from the interview with ST which results in the statement "I know how I can remain calm in finishing a math exam."

Researcher : What would you do, for example, in a math exam, the exam time is running out and you can't answer the questions?

ST : I will calm down and concentrate on answering the questions that have been given

Furthermore, there are four statements in the fourth indicator which is Adaptability Scale, the interview results in the statement "I try to persistently work on math problems until I get an answer."

Researcher: How would you react if you were given a math problem that you found difficult?

ST : I will try my best even if the answer is wrong, I will keep trying to solve it

The last is the fifth indicator which is Positive Impression Scale that has four statements, the interview results in the statement "I have positive ideas when studying mathematics."

Researcher : Why do you think we should study mathematics?

ST : I think mathematics is an important subject, I study accounting. Accounting and mathematics is two related subject, therefore I am very passionate about learning mathematics 


\section{The result of the interview with SS on each indicator of emotional intelligence}

The first indicator is Intrapersonal Skills which has four statements. One of the statements is "I do not easily ask when it is difficult to learn mathematics." The excerpt from the interview is as follows.

Researcher : What will you do if you have trouble learning math?

SS : I have never focused on studying mathematics, but because math is important, if I have difficulties, I will definitely ask my friends

Next, the second indicator is Interpersonal Skills which has four statements. Below is the excerpt from the interview with SS which results in the statement "I try to respect the way other people solve math problems."

Researcher : What makes it difficult for you to learn math?

SS : There are many problems that make it difficult for me, one of them is the teacher's teaching method

The third indicator is Stress Scale which concludes four statements. Below is the excerpt from the interview with SS which results in the statement "I know how I can remain calm in finishing a math exam."

Researcher : If during an exam, the way you solve the problem is different from your friend, and you think the answers are both correct. How do you react to it?

SS : I think there are many ways in maths, so it doesn't matter if my friends solve it differently.

The fourth indicator is Adaptability Scale which has four different statements. Below is the excerpt from the interview with SS which results in the statement "I try to persistently work on math problems until I get an answer."

Researcher : During a math exam, there is less time for the exam, and then you can't solve the questions. What are you going to do?

SS : I will answer the questions according to my ability and what I know.

The last is the fifth indicator which is Positive Impression Scale. There are four statements, and below is the excerpt from the interview with SS which results in the statement "I have positive ideas when studying mathematics."

Researcher : Why do you think we should study mathematics?

SS : Math is important even though my grades are bad, and I'm not good at math. I know math is important because in everyday life math is used.

\section{The result of the interview with SR on each indicator of emotional intelligence}

The first indicator is Intrapersonal Skills which has four statements. Below is the excerpt from the interview with SR which results in the statement "I do not easily ask when it is difficult to learn mathematics."

Researcher : What will you do if you have trouble learning math?

SR : Usually I ask friends

Furthermore, the second indicator is Interpersonal Skills. Below is the excerpt from the interview with SR which results in the statement "I try to respect the way other people solve math problems."

Researcher : What usually causes math to be difficult for you?

SR : The formula is difficult 
The third indicator is Stress Scale which has four different statements. The excerpt from the interview with SR results in the statement "I know how I can remain calm in finishing a math exam."

Researcher : If during an exam, the way you solve the problem is different from your friend, and you think the answers are both correct. How do you react to it?

SR

: Maybe I'll see my friend's work by cheating

Moreover, there are four statements in the fourth indicator which is Adaptability Scale. Below is the excerpt from the interview with SR which results in the statement "I try to persistently work on math problems until I get an answer."

Researcher : What if on a math test you can't solve the problem so your score is bad?

SR : No problem

In the fifth indicator which is Positive Impression Scale, the excerpt from the interview with SR which results in the statement "I have positive ideas when studying mathematics" is below.

Researcher : Why do you think we should study mathematics?

SR : Because mathematics is a compulsory subject in school

\section{Discussion}

Based on the interview excerpt on the first indicator, it can be seen that if ST has difficulty, it will be easier to control himself to learn. In line with previous research, it was said that students with high EI tend to be able to adjust and control themselves, besides that they also have a high interest in learning mathematics so they will try harder to learn mathematics (Purnama, 2016). Other research says that someone who is emotionally intelligent can develop confidence to achieve something by using the ability to control his behaviour, and emotionally ST has good skills (Chinyere \& Afeez, 2019; Ugwuanyi et al., 2020). Students who have high emotional intelligence also tend to be more active (Jannah et al., 2019). next Based on the interview excerpt on the second indicator, it turns out that ST is more confident with the results she achieves herself, even though her methods are different from those of her friends. According to Anwar, students with high EI tend to be more confident and wise in solving problems (Jan \& Anwar, 2019). Furthermore, based on the interview excerpt on the third indicator in difficult situations, ST can still concentrate calmly and responsibly answer the questions given. This is in line with previous research which states that students with high EI tend to be more prepared to face difficult situations and tend to be academically responsible (Mutmainah \& Rosyidah, 2017; Thomas \& Allen, 2021). Furthermore, based on the interview excerpt on the fourth indicator, it can be seen that ST continues to try to solve difficult math problems. Purnama said students with high EI tend to be better at facing obstacles and will try harder to solve them (Purnama, 2016). The last, based on the interview excerpt, ST considers mathematics as an important subject. Purnama and Tam stated that students with high EI tend to be more motivated to learn mathematics so that they can improve better academic achievement (Purnama, 2016; Tam et al., 2021). Next, the results of the interview analysis on SS were in the medium category.

Based on the interview excerpt on the first indicator, it can be seen that SS has a lower resistance than ST. In facing difficulties, SS could not solve it alone, but instead asked a friend. This is very unfortunate because asking friends means SS has less experience in learning, even though emotional intelligence can develop with their learning experiences $(\mathrm{Li}$, 2020). Mutmaindah \& Rosyidah's research said students with moderate EI did tend to have moderate mathematical thinking skills (Mutmainah \& Rosyidah, 2017). This causes SS in the learning process to never focus on lessons and is less able to explore its potential in depth. 
Next Based on the interview excerpt on the second indicator, SS experienced difficulties with the teaching method of the teacher in class. It should be noted that the methods used by teachers when teaching in class also affect students' interest in learning mathematics (Purnama, 2016). So to be able to improve this, teachers must participate in their teaching to implement emotionally intelligent learning (Pozo-Rico \& Sandoval, 2020). Furthermore, based on the interview excerpt on the third indicator, SS realizes that there are many ways to solve math problems, he can adjust to his social life so that when solving math problems in a different way from his peers, it doesn't matter to him. Other studies say students with good EI tend to be able to adjust to their social environment (Gebregergis et al., 2020; Purnama, 2016). Furthermore, based on the interview excerpt on the fourth indicator, it can be seen that SS has a fairly good mathematical ability because he has more confidence in his abilities. Mutmainah said students with moderate EI tended to have fairly good math skills (Mutmainah \& Rosyidah, 2017). SS also has good social and emotional skills in class so that it can complete academic assignments well and mediate challenges (Mahmud, 2020). Finally, based on the results of the fifth indicator interview excerpt, SS realizes that mathematics is important because it is used in everyday life (Dacillo, 2018). Because without realizing it, in everyday life everyone needs mathematics in various activities. Next, the results of the interview analysis on SR were in the low category.

Based on the interview excerpt on the first indicator, SR has low math ability so that in facing difficulties SR cannot solve it alone but depends on friends. Previous research has explained that students with low EI have low math abilities and tend to give up easily and in facing difficulties cannot solve their own problems (Mutmainah \& Rosyidah, 2017; Purnama, 2016). Next Based on the interview excerpt on the second indicator SR has difficulty in learning mathematics because of the difficult formula, it shows that SR has low mathematical and emotional resilience so that SR does not have the motivation to study mathematics more deeply. Previous research stated that students with low EI tend to have low academic motivation too so that in facing difficulties they cannot handle it (Fteiha \& Awwad, 2020). This is in line with Montgomery's research which states that the academic motivation of students with high, medium and low EI is different from one another (Montgomery et al., 2018). In accordance with SR, which has a low EI, it tends to have low motivation in mathematics. Furthermore, based on the interview excerpt on the third indicator, it can be seen that SR is easily discouraged and less able to solve a problem. According to Fteiha, students with low EI tend to give up more easily and cannot solve a problem Furthermore, based on the interview excerpt on the fourth indicator, SR looks stubborn and does not take any action if he gets a bad score. According to Purnama, students with low SR do tend to be stubborn (Purnama, 2016). Moreover, it can be seen that even though SR has a bad score, SR does not have motivation to learn. Whereas SR can focus more on learning and motivate oneself to improve academic achievement that is better than before Finally, based on the results of the fifth indicator interview excerpt, it can be seen that SR studied mathematics only to fulfill his obligations. Students with low EI have low personalities. Because this is influenced by the student's low EI rank. This is in line with Kurniawan's research which states that differences in the level of emotional intelligence also cause differences in students in solving problems (Kurniawan et al., 2017).

From the results of the analysis of ST, SS and SR, they are different according to the category of the research results where ST has high MR and Emotional Intelligence, SS has medium MR and Emotional Intelligence, and SR has low MR and Emotional Intelligence. This is in line with Joy's research which states that Emotional Intelligence is estimated to have a significant effect on MR (Joy, 2019). Mokhlesi's research shows that the level of a person's emotional intelligence does not depend on gender (Mokhlesi, 2019). Because the research results can differ according to the research instrument used. It can be concluded that 
emotional intelligence and mathematical resilience are interrelated and a person's emotional intelligence cannot be measured in terms of gender alone because other studies can produce different results according to the instrument used.

\section{CONCLUSION}

Mathematical Resilience is the personality of someone who is tough in adapting to face challenges and problems in all situations and conditions, especially in learning mathematics. Because mathematics is considered a difficult and abstract subject for students. So it is expected that students will have toughness in learning mathematics. Students who are strong in mathematics can face any obstacle and solve it emotionally intelligent. Emotional intelligence itself is a person's ability to solve problems through emotional control, motivate oneself to achieve a goal and the ability to build harmonious relationships in an environment. In the results of this study, the researchers found that mathematical resilience has a significant effect on students' emotional intelligence. However, the level of a person's emotional intelligence does not depend on gender. Students who have low mathematical resilience and emotional intelligence can hinder them during the mathematics learning process. So in learning mathematics, students need to improve their MR and emotional intelligence so that the objectives of learning mathematics can be achieved and achieve better achievement. In this study, there are limitations. First, the researchers suggest that future researchers can use a broader demographic. Next, other researchers also can do analysis MR with another mathematical thinking skill.

\section{REFERENCES}

Amelia, R., Kadarisma, G., Fitriani, N., \& Ahmadi, Y. (2020). The effect of online mathematics learning on junior high school mathematic resilience during COVID-19 pandemic. Journal of Physics: Conference Series, 1657(1). https://doi.org/10.1088/1742-6596/1657/1/012011.

Blaik Hourani, R., Litz, D., \& Parkman, S. (2020). Emotional intelligence and school leaders: Evidence from Abu Dhabi. Educational Management Administration and Leadership. https://doi.org/10.1177/1741143220913552.

Chinyere, O. T., \& Afeez, Y. S. (2019). Influence of emotional intelligence ability level of electrical/electronic technology university students on academic motivation and attitude to study. In International Journal of Electrical Engineering Education. https://doi.org/10.1177/0020720919840984.

Dacillo, L. V. (2018). Emotional Intelligence and Academic Achievements of Elementary Pupils in Mathematics of Batangas State University ARASOF Nasugbu, Batangas: Input to a Proposed Development Plan. KnE Social Sciences, 3(6), 862. https://doi.org/10.18502/kss.v3i6.2425.

Faradillah, A., \& Febriani, L. (2021). Mathematical Trauma Students' Junior High School Based on Grade and Gender. Infinity Journal, 10(1), 53. https://doi.org/10.22460/infinity.v10i1.p53-68.

Fteiha, M., \& Awwad, N. (2020). Emotional intelligence and its relationship with stress coping style. Health Psychology Open, 7(2). https://doi.org/10.1177/2055102920970416.

Gebregergis, W. T., Huang, F., \& Hong, J. (2020). The impact of emotional intelligence on depression among international students studying in China: The mediating effect of acculturative stress. International Journal of Intercultural Relations, 79(August), 8293. https://doi.org/10.1016/j.ijintrel.2020.08.008. 
Hadi, W., \& Faradillah, A. (2019). The Algebraic Thinking Process in Solving Hots Questions Reviewed from Student Achievement Motivation. Al-Jabar: Jurnal Pendidikan Matematika, 10(2), 327-337. https://doi.org/10.24042/ajpm.v10i2.5331.

Halimi, F., AlShammari, I., \& Navarro, C. (2020). Emotional intelligence and academic achievement in higher education. Journal of Applied Research in Higher Education, June. https://doi.org/10.1108/JARHE-11-2019-0286.

Harsela, K., Asih, E. C. M., \& Dasari, D. (2021). Level of mastery of mathematical skills and mathematical resilience. Journal of Physics: Conference Series, 1806(1). https://doi.org/10.1088/1742-6596/1806/1/012078.

Hendriana, H., Sumarmo, U., Carli, C., Ristiana, M. G., \& Putra, H. D. (2019). Enhancing students mathematical creative skill and resilience by using problem posing approach. Journal of Physics: Conference Series, 1318(1). https://doi.org/10.1088/17426596/1318/1/012065.

Hutauruk, A. J. B., Darmayasa, J. B., \& Priatna, N. (2019). Achievement of students mathematical resilience through problem based learning model with metacognitive approach. Journal of Physics: Conference Series, 1315(1). https://doi.org/10.1088/1742-6596/1315/1/012051.

Ishak, N. H. F. B., Yusoff, N. F. B. M., \& Madihie, A. (2020). Resilience in mathematics, academic resilience, or mathematical resilience?: An overview. Universal Journal of Educational Research, 8(5 A), 34-39. https://doi.org/10.13189/ujer.2020.081905.

Jan, S. U., \& Anwar, M. A. (2019). Emotional Intelligence, Library Use and Academic achievement of University Students. Journal of the Australian Library and Information Association, 68(1), 38-55. https://doi.org/10.1080/24750158.2019.1572482.

Jannah, N. M., Utomo, D. H., \& Handoyo, B. (2019). Pengaruh Kecerdasan Emosional Terhadap Hasil Belajar Akuntansi. Jurnal Pendidikan: Teori, Penelitian Dan Pengembengan, 1710-1714.

Johnston-Wilder, S., \& Lee, C. (2019). How can we Address Mathematics Anxiety more Efficiently as a Community? Theory and Practice: An Interface or A Great Divide?, 269-274. https://doi.org/10.37626/ga9783959871129.0.52.

Joy, U. C. (2019). Achievement Motivation And Emotional Intelligence As Predictors Of Mathematical Resilience Among Secondary School Students. Advances in Social Sciences Research Journal, 6(5), 191-200. https://doi.org/10.14738/assrj.65.6385.

Kooken, J., Welsh, M. E., McCoach, D. B., Johnston-Wilder, S., \& Lee, C. (2015). Development and Validation of the Mathematical Resilience Scale. Measurement and Evaluation in Counseling and Development, 49(3), 217-242. https://doi.org/10.1177/0748175615596782.

Kurniawan, E., Mulyati, S., \& Rahardjo, S. (2017). Proses Asimilasi Dan Akomodasi Dalam. Jurnal Pendidikan: Teori, Penelitian Dan Pengembengan, 2(5), 592-598.

Kustyarini, K. (2020). Self efficacy and emotional quotient in mediating active learning effect on students' learning outcome. International Journal of Instruction, 13(2), 663676. https://doi.org/10.29333/iji.2020.13245a.

Laelasari, Darhim, \& Prabawanto, S. (2019). Analysis of students' mathematics resilience abilities on linear program material. Journal of Physics: Conference Series, 1280(4), 8-12. https://doi.org/10.1088/1742-6596/1280/4/042005.

Li, C. (2020). A Positive Psychology perspective on Chinese EFL students' trait emotional intelligence, foreign language enjoyment and EFL learning achievement. Journal of Multilingual and Multicultural Development, 41(3), 246-263. https://doi.org/10.1080/01434632.2019.1614187.

MacCann, C., Jiang, Y., Brown, L. E. R., Double, K. S., Bucich, M., \& Minbashian, A. 
(2019). Emotional Intelligence Predicts Academic Performance: A Meta-Analysis. Psychological Bulletin, 146(2), 150-186. https://doi.org/10.1037/bul0000219.

Mahmud, A. (2020). A context-specific social and emotional learning programme to support adolescents following the transition to secondary school. Pastoral Care in Education, OO(00), 1-19. https://doi.org/10.1080/02643944.2020.1827285.

Mansir, F., \& Karim, A. (2020). Islamic Education Learning Approaches in Shaping Students' Emotional Intelligence in the Digital Age. Hayula: Indonesian Journal of Multidisciplinary Islamic Studies, 4(1), 67-86. https://doi.org/10.21009/004.01.04.

Moala, J. G., \& Hunter, R. (2019). Developing Mathematical Resilience Among Diverse Learners : Preliminary Progress and Problematics. 500-507.

Mokhlesi, V. (2019). A Study of Gender Differences in Emotional Intelligence and Learning Behaviour among Children. January. https://doi.org/10.25215/0604.047.

Montgomery, J., Mccrimmon, A., Climie, E., \& Ward, M. (2018). Emotional Intelligence in Atypical Populations: Research and School-Based Interventions. https://doi.org/10.1007/978-3-319-90633-1.

Muntazhimah, M., \& Ulfah, S. (2020). Mathematics resilience of pre-service mathematics teacher. International Journal of Scientific and Technology Research, 9(1), 14421445.

Mutmainah, S., \& Rosyidah, U. (2017). Analisis Kemampuan Berpikir Matematis Tingkat Tinggi Ditinjau dari Kecerdasan Emosional. JTAM | Jurnal Teori Dan Aplikasi Matematika, 1(1), 70. https://doi.org/10.31764/jtam.v1i1.385.

Nayar, S. K., Musto, L., Fernandes, R., \& Bharathan, R. (2020). Emotional Intelligence Predicts Accurate Self-Assessment of Surgical Quality: A Pilot Study. Journal of Surgical Research, 245, 383-389. https://doi.org/10.1016/j.jss.2019.07.051.

Ngui, G. K., \& Lay, Y. F. (2020). The effect of emotional intelligence, self-efficacy, subjective well-being and resilience on student teachers' perceived practicum stress: A Malaysian case study. European Journal of Educational Research, 9(1), 277-291. https://doi.org/10.12973/eu-jer.9.1.277.

Nugroho, M. A. C. A., Budiyono, B., \& Slamet, I. (2019). Experimentation of Interactive Setting Cooperative Learning Model (PSIK) and Course Review Horey (CRH) on The Material Geometry Flat Side Reviewed from Student Intelligence in The SMP N in Districk of Demak. Kreano, Jurnal Matematika Kreatif-Inovatif, 10(2), 125-131. https://doi.org/10.15294/kreano.v10i2.16831.

Okwuduba, E. N., Nwosu, K. C., Okigbo, E. C., Samuel, N. N., \& Achugbu, C. (2021). Impact of intrapersonal and interpersonal emotional intelligence and self-directed learning on academic performance among pre-university science students. Heliyon, 7(3), e06611. https://doi.org/10.1016/j.heliyon.2021.e06611.

Palumbo, R., Di Domenico, A., Piras, F., Bazzano, S., Zerilli, M., Lorico, F., \& Borella, E. (2020). Measuring global functioning in older adults with cognitive impairments using the Rasch model. BMC Geriatrics, 20(1), 1-14. https://doi.org/10.1186/s12877020-01886-0.

Pekaar, K. A., van der Linden, D., Bakker, A. B., \& Born, M. P. (2020). Dynamic self- and other-focused emotional intelligence: A theoretical framework and research agenda. Journal of Research in Personality, 86, 103958. https://doi.org/10.1016/j.jrp.2020.103958.

Permatasari, D., Maziyah, K. N., \& Fadila, R. N. (2021). Pengaruh Kemandirian Belajar Terhadap Mathematical Resilience Mahasiswa Dalam Pembelajaran Daring. Jurnal Cendekia: Jurnal Pendidikan Matematika, 5(1), 249-258. https://doi.org/10.31004/cendekia.v5i1.479.

Perry, M. A., Creavey, K., Arthur, E., Chance Humer, J., Lundgren, P. J., \& Rivera, I. (2020). 
Cultivating emotional intelligence in child welfare professionals: A systematic scoping review. Child Abuse and Neglect, 110(February), 104438. https://doi.org/10.1016/j.chiabu.2020.104438.

Pieronkiewicz, B., \& Szczygieł, M. (2020). How can parents and elementary school teachers promote resilience in young children through mathematical conversations? Early Child Development and Care, 190(10), 1604-1618. https://doi.org/10.1080/03004430.2019.1647189.

Pozo-Rico, T., \& Sandoval, I. (2020). Can Academic Achievement in Primary School Students Be Improved Through Teacher Training on Emotional Intelligence as a Key Academic Competency? Frontiers in Psychology, 10(January), 1-8. https://doi.org/10.3389/fpsyg.2019.02976.

Prayogi, S., Angraini, D. I., \& Oktafany. (2019). Hubungan Status Gizi , Status Psikososial dan Status Domisili Terhadap Indeks Prestasi Kumulatif ( IPK ) pada Mahasiswa Fakultas Kedokteran Universitas Lampung Relation of Nutritional Status , Psychosocial Status and Domicile Status to GPA of Students of. Medula, 9(1), 92-98.

Prentice, C., Dominique Lopes, S., \& Wang, X. (2020). Emotional intelligence or artificial intelligence- an employee perspective. Journal of Hospitality Marketing and Management, 29(4), 377-403. https://doi.org/10.1080/19368623.2019.1647124.

Purnama, I. M. (2016). Pengaruh Kecerdasan Emosional dan Minat Belajar Terhadap Prestasi Belajar Matematika di SMAN Jakarta Selatan. Formatif: Jurnal Ilmiah Pendidikan MIPA, 6(3), 233-245. https://doi.org/10.30998/formatif.v6i3.995.

Rohmah, S., Kusmayadi, T. A., \& Fitriana, L. (2020). International Journal of Multicultural and Multireligious Understanding The Effect of the Treffinger Learning Model on Mathematical Connection Ability Students Viewed from Mathematical Resilience. International Journal of Multicultural and Multireligious Understanding, 7(5), 275284.

Rokhmah, K. N., Retnawati, H., \& Solekhah, P. (2019). Mathematical resilience: Is that affecting the students' mathematics achievement? Journal of Physics: Conference Series, 1320(1). https://doi.org/10.1088/1742-6596/1320/1/012036.

Rosowsky, D. V. (2020). Defining resilience. Sustainable and Resilient Infrastructure, 5(3), 125-130. https://doi.org/10.1080/23789689.2019.1578166.

Ruqoyyah, S., Murni, S., \& Fasha, L. H. (2020). Microsoft Excel VBA on mathematical resilience of primary school teacher education students. Journal of Physics: Conference Series, 1657(1). https://doi.org/10.1088/1742-6596/1657/1/012010.

Tam, H. lin, Kwok, S. Y. C. L., Hui, A. N. N., Chan, D. K. yin, Leung, C., Leung, J., Lo, H., \& Lai, S. (2021). The significance of emotional intelligence to students' learning motivation and academic achievement: A study in Hong Kong with a Confucian heritage. Children and Youth Services Review, 121, 105847. https://doi.org/10.1016/j.childyouth.2020.105847.

Thomas, C. L., \& Allen, K. (2021). Driving engagement: investigating the influence of emotional intelligence and academic buoyancy on student engagement. Journal of Further and Higher Education, 45(1), 107-119. https://doi.org/10.1080/0309877X.2020.1741520.

Trigueros, R., Aguilar-Parra, J. M., Cangas, A. J., Bermejo, R., Ferrandiz, C., \& López-Liria, R. (2019). Influence of emotional intelligence, motivation and resilience on academic performance and the adoption of healthy lifestyle habits among adolescents. International Journal of Environmental Research and Public Health, 16(16). https://doi.org/10.3390/ijerph16162810.

Udayar, S., Fiori, M., \& Bausseron, E. (2020). Emotional intelligence and performance in a stressful task: The mediating role of self-efficacy. Personality and Individual 
Differences, 156(October 2019). https://doi.org/10.1016/j.paid.2019.109790.

Ugwuanyi, C. S., Okeke, C. I. O., \& Asomugha, C. G. (2020). Prediction of learners' mathematics performance by their emotional intelligence, self-esteem and selfefficacy. Cypriot Journal of Educational Sciences, 15(3), 492-501. https://doi.org/10.18844/cjes.v15i3.4916.

Wood, P. (2020). Emotional Intelligence and Social and Emotional Learning: (Mis)Interpretation of Theory and Its Influence on Practice. Journal of Research in Childhood Education, $34(1)$, 153-166. https://doi.org/10.1080/02568543.2019.1692104. 